\title{
船底トランスのスロット周辺に招ける スチフナ基部の疲労損傷について
}

\begin{tabular}{|c|c|c|c|c|c|c|}
\hline 正員 & 能 & 創* & 正員 & 片 & 岳 & 俊 \\
\hline 正員 & 口 欽 & 司** & 正員 & 嘉 & 本 & 時 \\
\hline 正員 & 辺 & 寛* & & & & \\
\hline
\end{tabular}

On Fatigue Damage of Web Stiffeners at Cut-outs of Bottom Transverses by Hajimu Mano, Member Toshioki Kataoka, Member

Kinji Sekiguchi, Member Tokio Kamoto, Member Hiroshi Kawabe, Member

\section{Summary}

A large number of cracks of web stiffeners on deep bottom transverses at their cut-outs which were provided to let longitudinals pass through them. It is required to estimate load condition of stiffeners at the cut-outs and fatigue strength of them.

In this paper authors describe about result of study on load condition of stiffeners and frequency of damaged stiffener, and some opinions about mechanism of initiation of the damage.

Authors study on the long-term distribution of wave induced lateral pressure on bottom shell including inside pressure caused by ship motions and estimate the distribution of wave induced stress of the stiffeners. From our study it is clarified that the distribution is described approximately by Weibull distribution (exponential distribution).

Supposing that the distribution of cycle of load to failure is described by logarithmic normal distribution, amplitude of still water stress is constant and distribution of wave stress is Weibull distribution, authors develop a new method of analyzing the relation between design stress and frequency of damaged stiffener. The method is very useful because it is also applied to analysis of fatigue damage of longitudinal member etc.

By our study the load condition in wing tank is evaluated to be worse, so it is expected that the frequency of wing tanks is higher than that of center tanks. From the result of inspection of actual ships, the same result is found. Character of the frequency, difference of the frequency by species of tank and by ships' age etc., estimated by our analysis is compared with the result of inspection in the same manner. It is concluded that damage affected by vibration of transverses may be found in the after tank part.

A new allowable value of design stress is guided by our method which is a little higher for stiffeners without back-brackets than the value which was suggested by the 120 th Research Committee of Shipbuilding Research Association of Japan.

\footnotetext{
* 防衛大学校

**防衛庁
} 


\section{1 緒 言}

大型船のトランスのスロット周辺に生じる損傷では, ウェブスチフナの基部の損傷が最も多く，これは基部に 働く応力による疲学が原因の主なものと考方られている。スチフナ基部の疲労強度については日本造船研究協会 第 120 研究部会に抢いて, 大規模な模型試験によって研究され, さらにその結果を適用した実船の疲労損傷解析 もなされた1)。この研究に招いては船体中央, 中心線上の船底外板に働く波浪荷重については研究されている が，これと船体の他の部分飞働く荷重の関係については明らかにされてない。

筆者等は上記の研究をさらに発展させて, 船底各部の波浪荷重の変化, さらにとれのタンクの使用条件による 変化等を研究した。次に, この荷重条件下で考兄られるスチフナ基部の疲労損傷発生率のスチフナの位置, タン クの種別による変化, あるいは損傷発生率の経年変化を求め, 実船の損傷調查結果と比較検討し, この種の損傷 の特性を究明した。

疲学損傷発生率の解析にあたっては, 船体構造部材のような静水応力と Weibull 分布飞従ら不規則変動応力 が負荷される場合の損傷発生率, あるいは損傷発生率がある許容值以下になるための設計応力を解析的に求める 方法を新た導いた。本方法はスチフナ基部だけでなく, 縦強度材等の疲労損傷解析にも応用できる有用な方法 といえる。

\section{2 荷重 条 件}

タンカー等のトランスのウェブ付スチフナの基部（ロンジ面材との取合部）に働く応力（基部の応力分布は均 一でないので, 以下に特いてはその最大応力を対象とする）は, ロンジからトランスに伝達される荷重によって 生じる応力と,トランスに加わる剪断力によって生じる応力の和または差で与兄られる。

船底トランスではロンジより伝達される荷重は，船底外板に働く圧力（内外圧の差）飞比例するから，それに よって生じる基部応力るまた，この圧力に比例して変化する。

任意の船底トランスに括いて, 隣接する外板（例を玄側タンク内の船底トランスにとると, 船側外板, 緃隔壁 板, または中央タンク内の船底外板が該当する）に働く圧力の影響を無視すると,トランスに加わる剪断力る圧 力に比例して変化するから，この剪断力によって生じる基部応力も近似的に圧力に比例するとみなせる。

したがって, 船底外板に働く圧力の変化を調べれば, 基部応力の変化も求められる。

\section{1 静水応力}

バラスト亭用タンクではバラスト状態では内部にバラストを満載するため, 次式で与兄られる静水圧力（外圧 を正とする） $p_{s b}$ が働く。

ここに $\rho g \cdots$ 単位体積当りの海水重量

$$
p_{s b}=\rho g\left(d_{b}-D\right)
$$

$$
d_{b} \cdots \text { バラスト契水 }\left(d_{b}=0.4 \sim 0.5 d, d \cdots \text { 満載契水 }\right)
$$

満載状態ではバラスト専用タンクは空であり, 次式で与えられる外圧 $p_{s f}$ が働く。

$$
p_{s f}=\rho g d
$$

$p_{s b}$ と $p_{s f}$ は符号は逆になるが, その絶対值はほぼ等しく, 基部には雨振りに近い変動応力が働く。この応力 は 1 航海が 1 周期という, 非常に長周期の変動応力である。

貨物油専用タンクは，バラスト状態では空であり，満載時には油を満載するため， $p_{s b}, p_{s f}$ はそれぞれ次のよ らになる。

$$
\left.\begin{array}{l}
p_{s b}=\rho g d_{b} \\
p_{s f}=\rho g d-\rho_{0} g D
\end{array}\right\}
$$

ここに, $\rho_{0} g \cdots$ 単位体積当りの貨物油重量

この場合は $p_{s f}$ は普通非常に小で, 圧力変動は片振り変動に近く，その振幅はバラスト専用タンクに比べると $1 / 4$ 程度になる。

バラスト兼用タンクは満載時は貨物油専用タンクと同条件となり, バラスト状態ではバラストの積载量によっ て変化するが，バラストを満載するとバラスト専用タンクの $p_{s b}$ に等しくなる。この場合も圧力変動は片振りに 近く，その振幅はバラスト専用タンクのそれの $1 / 2$ 程度になる。 
Fig. 1 は船底外板に加わる圧力の変化をモデル化し て示したものである。

\section{2 波浪応力}

船底外板には上記の長周期の圧力変化の上に, 比較 的周期が短かい航海中の波浪による圧力変化が重な る。したがって，スチフナ基部には静水中応力の変化 の上に, 波浪による圧力変化によって生じる波浪応力 が重なる。

\subsection{1 規則波中の波浪応力}

船が振幅 $h_{0}$ の規則波中を出会円周波数 $\omega_{e}\left(\omega_{e}\right.$ は 波長，船速，波に対する出会角によって変化する）で 航行するとき，船体中央に淤ける波面の変化 $h$ は次式 で与兄られる。

$$
h=h_{0} \cos \omega_{e} t
$$

この状態での船の上下摇 $\zeta$, 縦摇 $\phi$, 左右摇 $\eta$, 船首摇 $\psi$, 横摇 $\theta$ 抢よび船底外板に働く波浪変動圧

(外圧) $p$ はそれぞれ次式で与兄られるるのとする。

$$
\begin{aligned}
& \zeta=h_{0} \bar{\zeta}_{0} \cos \left(\omega_{e} t-\varepsilon_{\zeta}\right) \\
& \phi=k h_{0} \bar{\phi}_{0} \cos \left(\omega_{e} t-\varepsilon_{\phi}\right) \\
& \eta=h_{0} \bar{\eta}_{0} \cos \left(\omega_{e} t-\varepsilon_{\eta}\right) \\
& \phi=k h_{0} \bar{\psi}_{0} \cos \left(\omega_{e} t-\varepsilon_{\psi}\right) \\
& \theta=k h_{0} \bar{\theta}_{0} \cos \left(\omega_{e} t-\varepsilon_{\theta}\right) \\
& p=\rho g h_{0} \bar{J}_{\operatorname{J}} \cos \left(\omega_{e} t-\varepsilon_{j}\right)
\end{aligned}
$$

ここに, $\varepsilon_{\xi}, \varepsilon_{\phi}, \varepsilon_{\eta}, \varepsilon_{\psi}, \varepsilon_{\theta}, \varepsilon_{j} \cdots$ 位相角

$$
k=2 \pi / \lambda, \lambda \cdots \text { 波長 }
$$

船内にバラストまたは油を積載している場合は，上 記の動摇によって船底外板に働く変動内圧（下向きに 働く場合を正とする）を $\Delta p$ とすると，

$$
\Delta p \equiv \rho g h_{0} \bar{I} \cos \left(\omega_{e} t-\varepsilon_{i}\right)
$$

ここに, $\varepsilon_{i} \cdots$ 位相角

したがって, 船底外板慟く波浪变動圧 $p_{t}$ は次式 で与えられる。

$$
p_{t}=p-\Delta p \equiv \rho g h_{0} \bar{C} \cos \left(\omega_{e} t-\varepsilon_{c}\right)
$$

ここに, $\varepsilon_{c} \cdots$ 位相角

な拉, 記号, 座標位置, 出会角, 動摇, 変動圧の正 の方向等は Fig. 2 飞示す。

$\Delta p$ は上下方向加速度 $Z Z Z$ にる慣性力による成分 $\Delta p_{Z}$, 同様水平方向加速度に上る成分 $\Delta p_{Y}$, 横摇角加 速度によって生じる成分 $\Delta p_{\theta d}$ ，特よび横摇傾斜角によ って生じる成分 $\Delta p_{\theta S}$ の和となる。

$$
\Delta p=\Delta p_{Z}+\Delta p_{Y}+\Delta p_{\theta d}+\Delta p_{\theta s}
$$

上下方向加速度 $Z$ が働くときの圧力変化は Fig. 3 の ようになると考光 $\Delta p_{Z}$ は次式で与兄られるるのとす る。
Ballast cond. Full load cond.
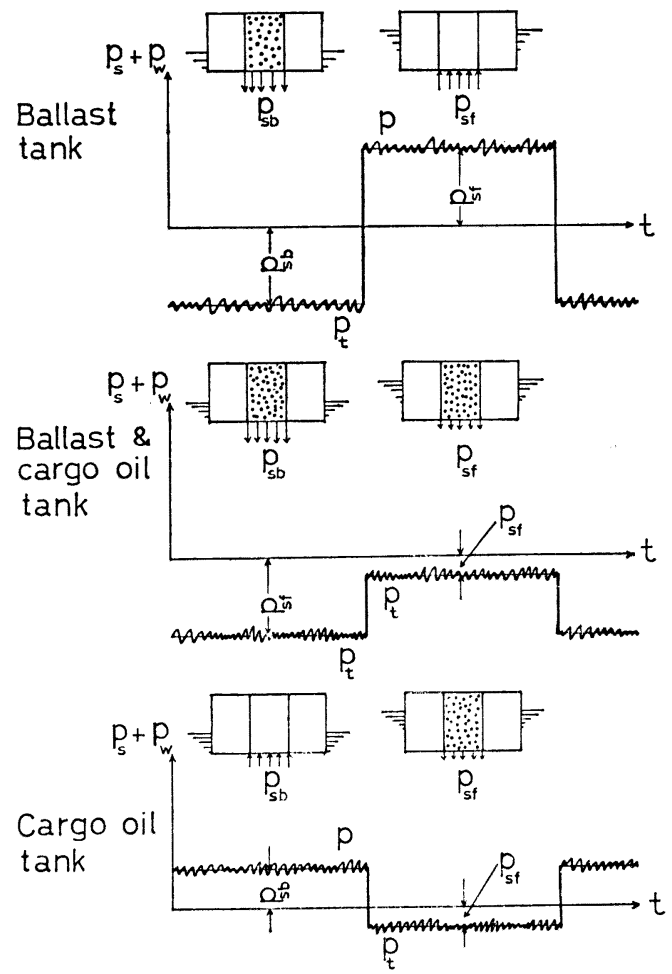

Fig. 1 Change of lateral load on bottom shell
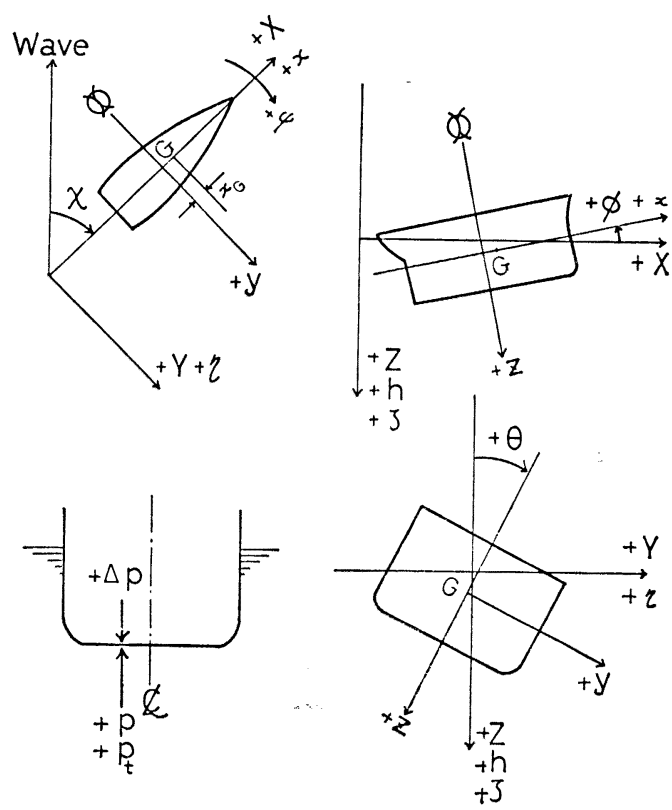

Fig. 2 Direction and definition of $p$, etc.

ここに, $\rho_{c} \cdots$ タンク内の液体の密度, バラスト満載時は $\rho$, 貨物油満載時は $\rho_{0}, D \cdots$ 船の深さ 


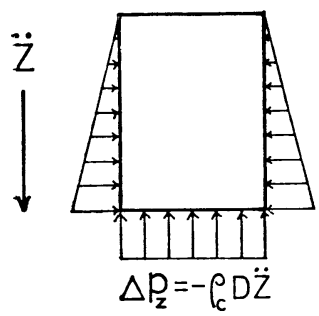

Fig.'3 $\Delta p_{2}$

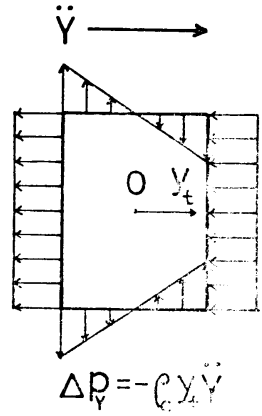

Fig. $4 \Delta p_{Y}$

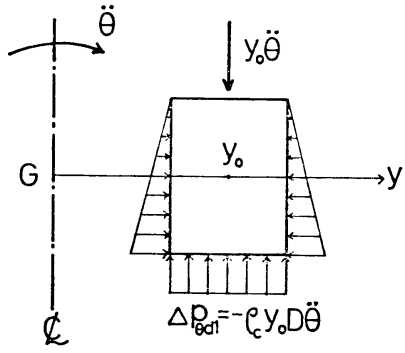

Fig. $5 \Delta p_{\theta d 1}$

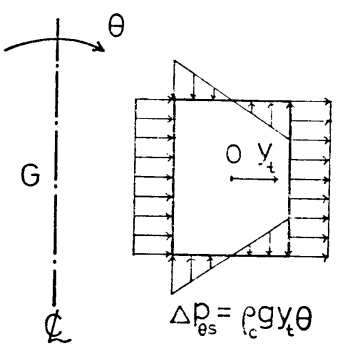

Fig. $6 \Delta p_{\theta s}$

船体の任意の位置 $x$ 飞拈けるZ̈は次式で与えられる。

$$
\ddot{Z}=\ddot{\zeta}-\left(x-x_{G}\right) \ddot{\phi}
$$

ここに, $x_{G} \cdots$ 重心位置

( 5 ), (9), (10)より $\Delta p_{z}$ は求められる。

$$
\Delta p_{Z}=\rho g h_{0}\left\{\bar{p}_{\zeta} \cos \left(\omega_{e} t-\varepsilon_{\zeta}\right)-\bar{p}_{\phi} \cos \left(\omega_{e} t-\varepsilon_{\phi}\right)\right\}
$$

ここに, $\quad \bar{p}_{\zeta}=\left(\rho_{c} / \rho\right)(D / L) \omega_{1}^{2} \bar{\zeta}_{0}$

$$
\begin{aligned}
\bar{p}_{\phi} & =\left(\rho_{c} / \rho\right)(D / L)\left(x-x_{G}\right) \omega_{1}^{2} k \bar{\phi}_{0} \\
\omega_{e}{ }^{2} & =(g / L) \omega_{1}^{2}=(g / L)\left\{\sqrt{2 \pi} \sqrt{L / \lambda}+2 \pi F_{n}(L / \lambda) \cos \chi\right\}^{2}
\end{aligned}
$$

$L \cdots$ 船の長さ， $\lambda \cdots$ 波長， $\chi \cdots$ 出会角, $F_{n} \cdots$ 船速 (フルード数)

水平加速度 $\ddot{Y}$ が働くときの圧力変化を Fig. 4 の形になると考えタンクの中心より $y_{t}$ の位置における $\Delta p_{Y}$ は 次式で与えられるものとする（タンク中心の甲板の圧力は変化しないとする）。

$$
\Delta p_{Y}=-\rho_{c} y_{t} \ddot{Y}
$$

船体の任意の位置 $x$ に括ける $\ddot{Y}$ は次式で与えられる。

$$
\ddot{Y}=\ddot{\eta}+\left(x-x_{G}\right) \ddot{\psi}
$$

( 5 ), (12), (13)より $\Delta p_{Y}$ は求められる。

$$
\Delta p_{Y}=\rho g h_{0}\left\{\bar{p}_{\eta} \cos \left(\omega_{e} t-\varepsilon_{\eta}\right)+\bar{p}_{\psi} \cos \left(\omega_{e} t-\varepsilon_{\psi}\right)\right\}
$$

ここに, $\bar{p}_{\eta}=\left(\rho_{c} / \rho\right)\left(y_{t} / L\right) \omega_{1}^{2} \bar{\eta}_{0}$

$$
\bar{p}_{\psi}=\left(\rho_{c} / \rho\right)\left(y_{t} / L\right)\left(x-x_{G}\right) \omega_{1}^{2} k \bar{\phi}_{0}
$$

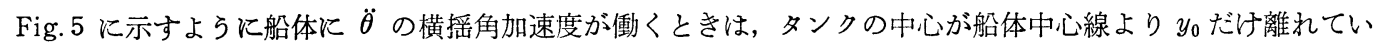
るタンクでは, 上下方向加速度 $y_{0} \ddot{\theta}$ が働くと同時に, タンクの中心を軸として角加速度が $\ddot{\theta}$ の回転運動をす る。前者によって船底外板に動く内圧 $\Delta p_{\theta d 1}$ は $\Delta p_{Z}$ と同様に次式で与えられる。

$$
\Delta p_{\theta d 1}=-\rho_{c} y_{0} D \ddot{\theta}
$$

$\Delta p_{\theta d 1}$ は中央タンクでは 0 となる。

(5)，(15)より $\Delta p_{\theta d 1}$ は求められる。

$$
\Delta p_{\theta d 1}=\rho g h_{0} \bar{p}_{\theta d 1} \cos \left(\omega_{e} t-\varepsilon_{\theta}\right)
$$

ここに, $\bar{p}_{\theta d 1}=\left(\rho_{c} / \rho\right)(D / L) y_{0} \omega_{1}^{2} k \bar{\theta}_{0}$

深さを $D$ とすれば次式で与えられる。

$$
\Delta p_{\theta d 2}=\rho g h_{0} \bar{p}_{\theta d 2} \cos \left(\omega_{e} t-\varepsilon_{\theta}\right)
$$

ここに, $\bar{p}_{\theta d 2}=\left(\rho_{c} / \rho\right)(D / L) B_{t} \phi\left(y_{t}, z\right) \omega_{1}{ }^{2} k \bar{\theta}_{0}$

$$
\begin{gathered}
\phi\left(y_{t}, z\right)=\sum_{n=0}^{\infty}\left[A_{n} \sin \{(\pi / D)(2 n+1) z\} \sinh \left\{(\pi / D)(2 n+1) y_{t}\right\}\right. \\
-B_{n} \sin \left\{\left(\pi / B_{t}\right)(2 n+1) y_{t}\right\} \sinh \left\{\left(\pi / B_{t}\right)(2 n+1) z\right\}
\end{gathered}
$$




$$
B_{n}=\frac{(-1)^{n}}{\pi^{3}} \frac{4\left(D / B_{t}\right)}{(2 n+1)^{3} \cosh \left\{(\pi / 2)\left(B_{t} / D\right)(2 n+1)\right\}}
$$

$\Delta p_{\theta d 2}$ は普通のタンクの寸法では $\Delta p_{\theta d 1}$ の $10 \%$ 程度であるので無視することにする。

横摇によって $\theta$ の傾斜を生じたときのタンクの中心より $y_{t}$ の位置における $\Delta p_{\theta s}$ は次式で与えられるものと する (Fig. 6 参照)。

$$
\Delta p_{\theta s}=\rho_{c} g y_{t} \theta
$$

( 5 ), (17)より $\Delta p_{\theta S}$ は求められる。

$$
\Delta p_{\theta S}=\rho g h_{0} \bar{p}_{\theta s} \cos \left(\omega_{e} t-\varepsilon_{\theta}\right)
$$

ここに, $\bar{p}_{\theta s}=\left(\rho_{c} / \rho\right) y_{t} k \bar{\theta}_{0}$

Table 1 Principal paticulars of a tanker supposed in estimation of lateral pressure on bottom shell

\begin{tabular}{lc|c|c}
\hline & Load condition & Full load & Ballast \\
\hline Item & $(\mathrm{m})$ & $302.0 \times 50.4 \times 24.3$ \\
$L_{P P} \times B \times D$ & $(\mathrm{~m})$ & 18.61 & 5.92 \\
$d$ & $(\mathrm{t})$ & 236,250 & 67,780 \\
Displacement & $C_{b}$ & 0.814 & 0.734 \\
Block coef. & $(\mathrm{m})$ & 8.555 & $-3.347^{*}$ \\
$G_{\varnothing}\left(x_{G}\right)$ & &
\end{tabular}

* - - ..means aft side

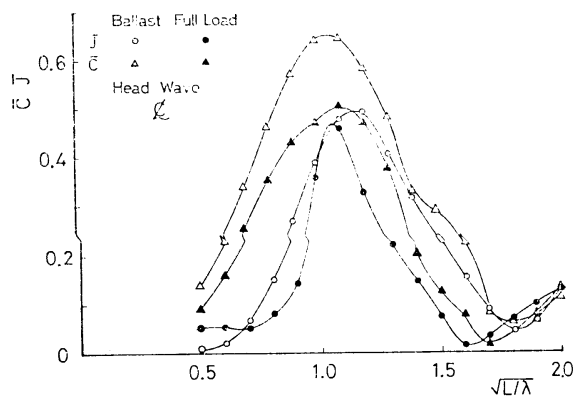

Fig. 7 Frequency-response function of lateral pressure on bottom shell

以上の各式と $(7)$ から $p_{t}$ が求められる。Fig. 7 は Table 1 に示す船がフルード数 $\left(F_{n}\right) 0.1$ で規則波中を向

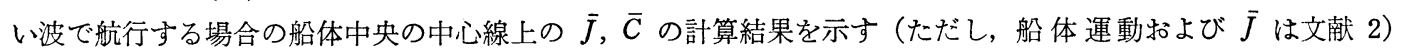
のプログラムによる計算值である)。

\section{2 .2 不規則波中の波浪応力}

船が任意の航行条件で波高 $H_{i}$, 波周期 $T_{j}$ の不規則 波中を航行するときは， $p, p_{t}$ は不規則変動となるが， 任意の規則波中を任意の航行条件で航行するときの応答 関数が与えられるならこれらの変動圧の短期および長 期分布は線形重小合わせ法によって求められる。

Fig. 8 は Table 1 に示す船が北大西洋（海象は Walden の波浪統計を想定した）を長期航海する場合に，船 底各部（横断面 $2^{1} / 2 ， 5(\varnothing), 7^{1} / 2$ に打ける船体中心線 とビルジ部）に働く $p, p_{t}$ のピーク值の長期分布を, 前 述の才法によって求めた応答関数を使用し, 文献 3）に 示される方法によって計算した結果の一例を示す。な 特，任意の波高および波周期の海面は ISSC スペクトル で表わされるとした。

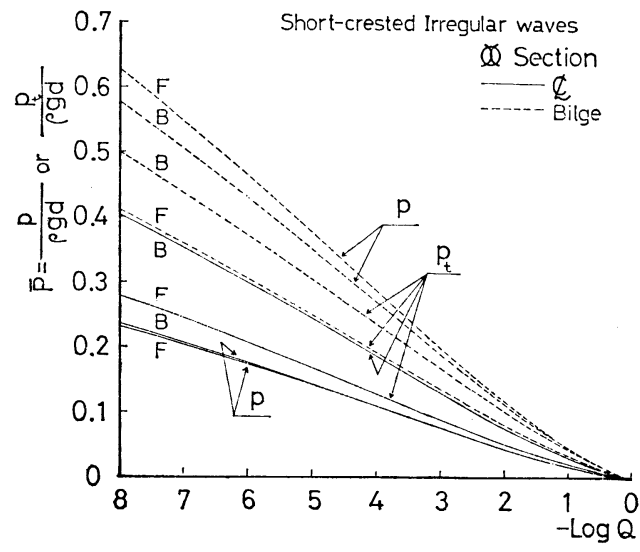

Fig. 8 Long-term distribution of lateral load on bottom shell (North Atlantic)

文献 4）に示すように，船は最悪海面状態を航行するときの航行条件で全生涯を航行すると想定できるので, 船は就航速力より低速 $\left(F_{n}=0.1\right)$ で, 短波頂不規則波中を常に向い波で航行するとした。困より船底外板に加 わる压力も一般の波浪応答と同様に，Weibull 分布（同図の場合は指数分布）で近似できることが判る。

スチフナ基部の波浪応力も $p, p_{t}$ に比例するから, 同じ分布になる。

\section{3 タンクの使用条件による荷重条件の变化}

スチフナ基部（最大）応力は，船底外板に満載契水の水頭に等しい圧力 $\rho g d か ゙$ 加わったときの值を基準値 $\sigma_{\max }$ とし，この基準值に対する比 クで表わす。

バラスト専用タンクでは前記の静水応力の変化の上に重なる波浪応力は, バラスト状態ではバラストを浾載し ているから， $p_{t b}$ (以下に拉いて添字 $b$ はバラスト状態， $f$ は満載状態を示す）によって生じた波浪応力, 満載状 
態では空であるから， $p_{f}$ によって生じた波浪応力である。

貨物油タンクでは前記の静水応力の変化の上に, バラスト状態では空, 満載状態では貨物油を満載するから, 前者では $p_{b}$, 後者では $p_{t f}$ による波浪応力が重なる。

同様, バラスト兼用タンクでは前二者と異なる静水応力の変化の上に, 使用条件からパラスト状態で $p_{t b}$, 満 載状態で $p_{t f}$ による波浪応力が重なる。

荷重条件はタンクの使用条件で変化する上に, 波浪応力は位置によって異なるから, 非常に複 雑である。Fig. 9 は各タンクに働く波浪応力の 超過確率が $10^{-8}$ のときの極値を比較したもの である。罒の綎軸は極值と $\sigma_{\max }$ の比であって, 応力は圧力に比例するから Fig. 8 の綎軸と值は 一致する。玄側タンクの值はタンクの幅は $B / 4$ であるとして, 中心線から $3 B / 8$ 離れた点の圧 カによる応力である。なお，この点の圧力は中心 線とビルジ部の值から插間法によって求めた。

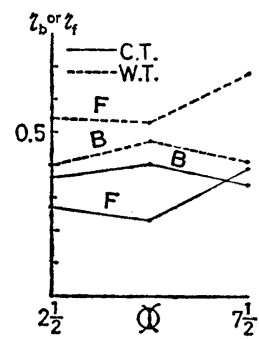

a. Ballast tank

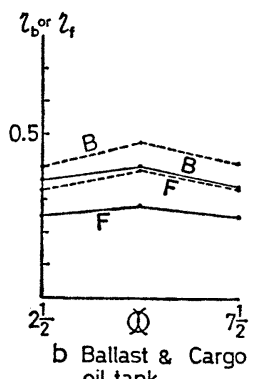

Ballast 8
oil tank

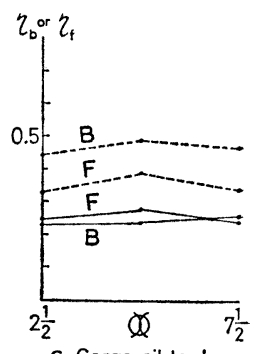

C Cargo oil tank

Fig. 9 Extreme value $\left(Q=10^{-8}, N\right.$. A.) of wave induced stress of stiffener $\left(\eta_{b}, \eta_{f} \cdots\right.$ Ratio of extreme value to $\sigma_{\max }$ )

波浪応力の船長方向の変化は船首部玄側バラストタンク以外は一般に顕著でなく, 船体中央の值で代表させて あよい。玄側タンクと中央タンクとでは明らかに差があり，前者の方が相当苛酷である。また中央タンクでは内 压により荷重が増加して舕り，タンクにバラストまたは油を積載した状態の方が苛酷であるが，逆に玄側タンク では内圧は外圧を相殺する働きがあり，空タンクが最も悪い条件となる。

\section{3 スチフナ基部の疲労強度}

\section{1 模型のスチフナ基部疲労強度}

日本造船研究協会第 120 研究部会 (SR 120 部会) では 10 万 DWT タンカーの船底トランスの一部を約 $1 / 4$ に縮小したスロット部の構造が種々異なる模型を使用して，スチフナ基部の疲労強度を試験（片振荷重）した。 この試験結果から, 三井千葉研の計算式) によって求められたスチフナ基部応力（最大応力）の振幅 $\sigma_{a}$ と, 寿 命 $N$ の関係を求めると, Fig. 10 が得られる。眓から $\sigma_{a}$ と $N$ 関係は次式で表わされる。

$$
\log N=b_{m}-a \log \sigma_{a}
$$

ここに, $b_{m}, a \cdots$ 係数 (Table 2 参照)

しかし, 詳細に観察すると, 普通の構造のように基部 に偏心曲げモーメントが働く型（偏心型）と, ハックブ ラケットで基部を補強され基部に偏心曲げモーメントが 働かないるの（釣合型）とではやや寿命に差があり, 偏 心型の試験結果は分布範囲の上部に多く, 釣合型のそれ は下部に多い。したがって, 両者の結果を 1 本の $S-N$ 線図で表わしても実用上十分な精度を有するが，これを 偏心型, 釣合型のそれを別個の $S-N$ 線図で表わす方が より精度のよい結果が得られると期待される。以上の 3 種の $S-N$ 線図の係数 $b_{m}, a$ を Table 2 飞示す。

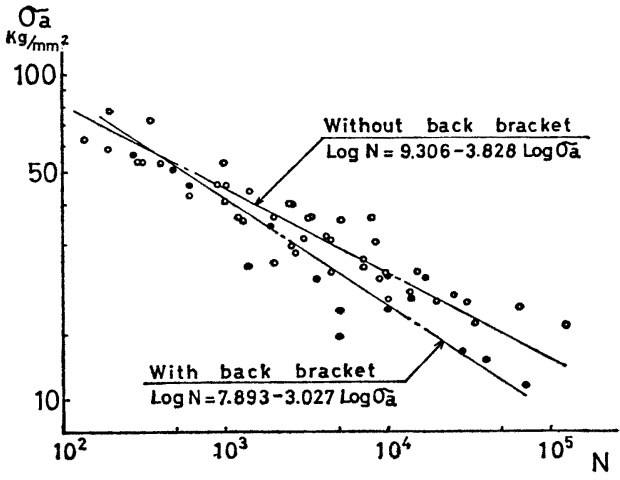

Fig. 10 Results of model test by SR 120 ( - ..with back bracket)

$S-N$ 線図が構造によって異なるのは不合理であるが，応力計算式が全般的に偏心型に対してはやや高めに応力

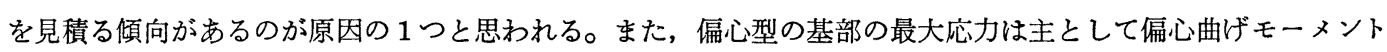
によって生じたものであり，釣合型のそれは基部の切欠きによる応力集中にょって生じたもので，応力勾配に差 があるのる原因の 1 つといえる。

Table 2 に(19)による計算值を基準とした, 試験結果のバラッキの標準偏差 $s_{m}$ を次式で求めた結果を示す。

$$
s_{m}=\left[\frac{1}{n-1} \sum_{i=1}^{n}\left\{\log N(i)-\left(b_{m}-a \log \sigma_{a}(i)\right)\right\}^{2}\right]^{1 / 2}
$$


Table $2 S$ - $N$ diagrams corresponding to $50 \%$ failure probability estimated from model test

\begin{tabular}{|c|c|c|c|c|}
\hline \multicolumn{2}{|c|}{$\begin{array}{lr}\text { Failure } \\
\text { type }\end{array}$} & $\begin{array}{l}\text { Initiation } \\
\text { of crack }\end{array}$ & $\begin{array}{c}\text { Length of } \\
\text { crack } 10 \mathrm{~mm}\end{array}$ & $\begin{array}{l}\text { Failure of } \\
\text { stiffener }\end{array}$ \\
\hline \multirow{3}{*}{ All model } & $a$ & 3.353 & $3.353^{*}$ & 3.491 \\
\hline & $b_{m}$ & 8.519 & 8.943 & 9.742 \\
\hline & $s_{m}$ & 0.303 & 0.421 & 0.495 \\
\hline \multirow{3}{*}{$\begin{array}{l}\text { Without back } \\
\text { bracket }\end{array}$} & $a$ & 3.828 & $3.828^{*}$ & 4.071 \\
\hline & $b_{m}$ & 9.306 & 9.995 & 10.769 \\
\hline & $s_{m}$ & 0.259 & 0.273 & 0.441 \\
\hline \multirow{3}{*}{$\begin{array}{l}\text { With back } \\
\text { bracket }\end{array}$} & $a$ & 3.027 & $3.027 *$ & 3.046 \\
\hline & $b_{m}$ & 7.893 & 8.385 & 8.610 \\
\hline & $\boldsymbol{s}_{m}$ & 0.316 & 0.381 & 0.256 \\
\hline \multicolumn{2}{|l|}{ Remark } & \multicolumn{3}{|c|}{$\begin{array}{l}a, b_{m} \cdots \text { Coef. of } S \text { - } N \text { diagram, } \\
\text { when it is fitted by Eq. (19) } \\
s_{m} \cdots \text { Standard deviation of } \log N \\
* \text { Estimated value from that of } \\
\text { crack initiation }\end{array}$} \\
\hline
\end{tabular}

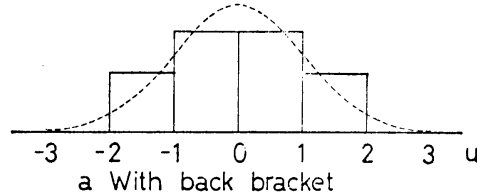

a With back bracket
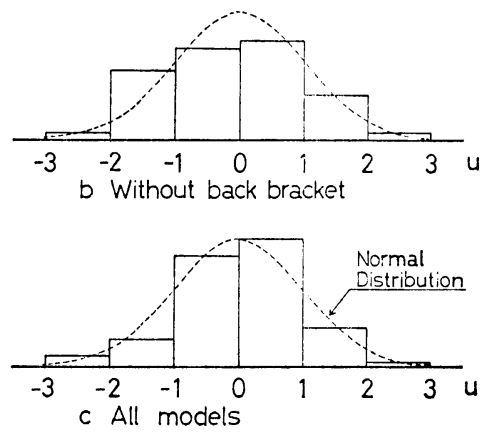

Fig. 11 Histogram of deviation of test result from estimated valve by Eq. (19) $u=\left\{\log N(i)-\left(b_{m}-a \log \sigma_{a}(i)\right)\right\} / s_{m}$

ここに, $\quad n \cdots$ 供試模型数

$N(i) \cdots$ 任意の模型 $i$ の寿命

$\sigma_{a}(i) \cdots$ 任意の模型 $i$ の応力振幅

表より明らかなように偏心型の $s_{m}$ は，全体を1本の $S-N$ 線図にしたときのとれより若干小さい。前記の計 算式の誤差は同構造のものでは影響しなくなるから, 偏心型の $s_{m}$ が基部の疲労強度の有するバラッキを最も正 確に表わしたるのといえる。釣合型の $s_{m}$ は小ではないが，これは試料数が少ないことも原因の1つといえる。

（19）による計算值を基準とした試験結果のバラッキを図示すると Fig. 11 が得られる。試料数が少ない釣合型 では明らかではないが, 偏心型, 全試験結果の順に試料数が増加するとともに正規分布に近い形になる。したが って, 疲労寿命は(19)で求められる值を中位值 (メジアン) とし, Table 2 に示す $s_{m}$ を標準偏差とする対数正 規分布に従うとみなせる。

Table 2 飞示す標準偏差の值は文献 6)，7）に示された值に比べやや大である。これは素材の疲労試験とは異 なり本模型では継手部の溶接によって疲労強度が左右されるが, 溶接継手は溶接脚長, 溶着金属の止端 部の形 状，ルートギャップ等にバラッキがあり，当然疲労強度も素材に比べ大きなバラッキを有するためと見られる。 これは実船でも同様で同条件のスチフナに拉いても，損傷は相当の時間差を持って発生するのが普通である。し たがって，スチフナ基部の疲労強度はこのバラッキを考慮して検討すべきである。

この標準偏差の応力振幅による变化は無視できるものとし，寿命は対数正規分布に従って分布するるのとする と, 任意の損傷発生率 $P_{f}$ に対応する $S-N$ 線戝は Table 2 に示す $s_{m}$ を使用して容易に求められ，これは(19) で求められる $S-N$ 線図に平行な直線となる。これは疲労損傷発生率の解析に执いて係数 $b_{m}$ が Table 2 に示 す値を中位値とし，同表の $s_{m}$ を標準偏差とする正規分布に従う確率变数であるとみなせばよいことを意味す る。

\section{2 実船のスチフナ基部疲労強度}

文献 1）によれば実船のスチフナ基部の疲労強度を表わす $S-N$ 線図は, 模型のそれを寸法効果と腐蝕影響に ついて修正したものになる。

寸法効果については模型のスチフナ板厚は $4 \mathrm{~mm}$ であり，板厚が $16 \mathrm{~mm}$ のときは同一寿命に対する $\sigma_{a}$ は 0.7 倍に低下寸る。板厚が $20 \mathrm{~mm}$ 程度までは寸法効果は板厚とともに直線的に変化するとみても大きな詔差は ない。したがって，寸法効果に対しては次式で与えられる修正值 $\Delta b_{t s}$ を(19)の $b_{m}$ に加えればよい。

$$
\Delta b_{t s}=a \log \left(1.1-0.025 t_{s}\right)
$$


ここに， $t_{\mathrm{s}} \cdots$ スチフナの板厚 $(4 \sim 20 \mathrm{~mm})$

腐蝕の影響は $\sigma_{a}$ によって異なるが，一応腐蝕によって寿命が一様に比率 $\beta$ だけ低下するものとする。この場 合は(19)の $b_{m}$ に次の修正值 $\Delta b_{c}$ を加劣ればよい。

$$
\Delta b_{c}=\log \beta
$$

以上から実船のスチフナ基部の疲労強度を示す $S-N$ 線戝は次式で与兄られる。

$$
\begin{aligned}
\log N & =\left(b_{m}+\Delta b_{t s}+\Delta b_{c}\right)-a \log \sigma_{a} \\
& \equiv b-a \log \sigma_{a}
\end{aligned}
$$

模型の寿命のバラッキそ示す $s_{m}$ と実船のそれとの間の差は大きくないと思われるが十分な資料はないから， 実船の損傷実績をみて修正するのが妥当といえる。 $\Delta b_{c}$ す実船の損傷実績から決定しなければならない。実船に おいては腐蝕影響は平均値が $\Delta b_{c}$, 標準偏差が $s_{c}$ である確率変数とみなさねばならないことが多いと推定され る。この場合は (23)の係数 $b$ は中位值が $b$ であり, 標準偏差 $s_{s}$ は次式で求められる確率変数（本稿では正規分 布とする) として取扱えばよい。

$$
s_{s}=\left(s_{m}^{2}+s_{c}^{2}\right)^{1 / 2}
$$

したがって， $s_{s}$ は $s_{m}$ より相当大きな値になることが多いといえる・

$\sigma_{a}$ が非常に小になったとき，あるいは非常に大となったときには， $S-N$ 線図は（23）では表わせない。 $\sigma_{a}$ が 小となると疲労限の存在が考号られるが, 実船は腐蝕環境下にあり, 前述のようにランダム荷重が負荷されるの で，S-N 線困は疲労限以下の $\sigma_{a}$ に対しても(23)が適用でさると考学る。また，降伏点を超える $\sigma_{a}$ は基部に働 くことは考兄られるが，これらは弾性計算で求めた值であるから，そのような $\sigma_{a}$ に対する寿命は(23)より求め られる值より大となるが一応この場合る(23)が適用できるものとする。

模型試験に和けるクラック発生寿命というのは実験室的なクラック発生寿命であり, 実船でのクラック発生寿 命とは相当異なると推定されるので, 模型試験に特けるクラックが $10 \mathrm{~mm}$ 進展時の寿命が, 実船に特けるクラ ック発生寿命に対応するものとする。

\section{4 疲労損傷発生率の推定法}

\section{1 損甥発生条件に対する仮定}

スチフナ基部には長周期の定振幅の静水応力に重複して, 短周期の指数分布に従う波浪沁力が負荷されて招 り，荷重条件は縦強度材等と同型である。このような場合の疲労強度の解析には，波浪応力に対する疲労強度に 与古る平均応力（静水応力が相当する）の影響が明らかにされねばならない。SR 120 部会の模型試験では 6 個 の模型を使用して，片振荷重以外の荷重条件の試験を実施し，平均応力は相当高い場合でも寿命に影響を与充な いといら結果が得られた。ただし，実船では平均応力も長周期の変動をするから，それによる疲労被害が考えら れる。

ここでは平均応力の影響は無視して, 問題もあるが, 静水応力が単独で働く場合の疲労被害度 $D_{s}$ と, 波浪灾 カが単独で働く場合の疲労被害度 $D_{w}$ の和を疲労被害度とし, これが一定值に達すると損傷が発生すると仮定し て解析する。

\section{2 疲労被害度}

4.2.1 静水応力による疲労被害度

スチフナ基部最大応力の基準値が $\sigma_{\max }$ で, 静水応力の振幅が $\eta_{s} \sigma_{\max }$ とすると，この定振幅の応力が負荷さ れるときの基部の寿命 $N_{s}$ は(23)より求められる。

$$
N_{s}=10^{b}\left(\eta_{s} \sigma_{\max }\right)^{-a}
$$

この応力の繰返し数を $n_{s}$ とすると， $D_{s}$ は次のようになる。

$$
D_{s}=n_{s} / N_{s}=10^{-b} g_{s}(\eta) \sigma_{\max }{ }^{a}
$$

ここに, $g_{s}(\eta)=n_{s} \eta_{s}{ }^{a}$

4.2 .2 波浪応力による疲学被害度

説明の都合上，バラスト状態に括ける波浪応力による疲学被害度 $D_{w b}$ につて述べる。波浪応力は指数分布 北従らことから, $\sigma_{w} \sim \sigma_{w}+d \sigma_{w}$ の応力の負荷回数 $n_{w}(\sigma)$ は次式で求められる。

$$
n_{w}(\sigma)=\left(n_{w} / \lambda_{w}\right) \exp \left[-\left(\sigma_{w} / \lambda_{w}\right)\right] d \sigma_{w}
$$


ここに, $\quad \lambda_{\omega} \cdots$ 波浪応力の平均值

$n_{w b} \cdots$ バラスト状態の波浪応力の負荷回数

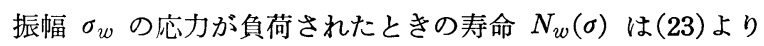

$$
N_{w}(\sigma)=10^{b}\left(\sigma_{w}\right)^{-a}
$$

$n_{w}(\sigma)$ と $N_{w}(\sigma)$ の比がこの応力による被害度になる。よって, 全波浪応力による被害度 $D_{w b}$ は次のようになる。

$$
D_{w b}=\int_{0}^{\eta_{b} \sigma_{\max }} 10^{-b} \sigma_{w}{ }^{a}\left(n_{w} / \lambda_{w}\right) \exp \left[-\left(\sigma_{w} / \lambda_{w}\right)\right] d \sigma_{w}
$$

ここに, $\eta_{b} \sigma_{\max } \cdots$ バラスト状態に㧧ける波浪応力の極值

上記の極值は超過確率 $Q(\sigma)$ が $1 / n_{w b}$ になる波浪応力の值であり，波浪応力が指数分布に従らから

$$
\boldsymbol{Q}(\sigma)=\exp \left[-\left(\sigma_{w} / \lambda_{w}\right)\right]
$$

したがって，

$$
\lambda_{w}=\eta_{b} \sigma_{\max }\left(\ln n_{w b}\right)^{-1}
$$

（31）を(29)に代入すると次式が得られる。

$$
\begin{aligned}
D_{w b} & =10^{-b} n_{w b}\left\{\left(\eta_{b} \sigma_{\max }\right) /\left(\ln n_{w b}\right)\right\}^{a} \int_{0}^{\ln n_{w b}} t^{a} e^{-t} d t \\
& \fallingdotseq 10^{-b} n_{w b}\left\{\left(\eta_{b} \sigma_{\max }\right) /\left(\ln n_{w b}\right)\right\}^{a} \Gamma(a+1)
\end{aligned}
$$

ここに, $t=\sigma_{w} / \lambda_{w}$

$$
\Gamma(a+1)=\int_{0}^{\infty} t^{a} e^{-t} d t
$$

同様に満載状態に括ける波浪応力による被害度 $D_{w f}$ は, 次のようになる。

$$
D_{w f} \fallingdotseq 10^{-b} n_{w f}\left\{\eta_{f} \sigma_{\max } /\left(\ln n_{w f}\right)\right\}^{a} \Gamma(a+1)
$$

ここに, $\eta_{f} \sigma_{\max } \cdots$ 満載状態に拈ける波浪応力の極值

(32), (33)より,

$$
D_{w}=D_{w b}+D_{w f}=10^{-b} g_{w}(\eta) \sigma_{\max }^{a}
$$

ここに, $g_{w}(\eta)=n_{w}\left(\ln n_{w}\right)^{-a} \Gamma(a+1)\left(\eta_{b}{ }^{a}+\eta_{f}{ }^{a}\right), n_{w}=n_{w b}=n_{w f}$

\section{3 疲労損傷発生率}

$D_{s}$ と $D_{w}$ の和がある值 $D_{f}$ 以上になると損傷が発生するとすると，(26)，(34)より，

$$
D_{s}+D_{w}=10^{-b} g(\eta) \sigma_{\max }{ }^{a}
$$

ここに, $g(\eta)=g_{s}(\eta)+g_{w}(\eta)$

よって, 次式が成立するとき損傷が発生する。

$$
b<\log g(\eta)+a \log \sigma_{\max }-\log D_{f}
$$

$b$ は中位值が $b$, 標準偏差が $s_{s}$ の確率変数であるから, 損傷発生率 $P_{f}$ は次式によって求められる。

$$
P_{f}=P\left[b<\left(\log g(\eta)+a \log \sigma_{\max }-\log D_{f}\right)\right]
$$

ここでは， $b$ は正規分布に従らとしているから， $P_{f}$ は次式で与えられる。

$$
P_{f}=\Phi(u)
$$

ここに, $u=\left\{\left(\log g(\eta)+a \log \sigma_{\max }-\log D_{f}\right)-b\right\} / s_{s}$

$$
\Phi(u)=\frac{1}{\sqrt{2 \pi}} \int_{-\infty}^{u} e^{-u^{2} / 2} d u
$$

上式から， $P_{f}$ が任意の值 $P_{f 0}$ になるときの $\sigma_{\max }$ の值を求めることもできる。同式から $P_{f}$ が $P_{f 0}$ になる ときの $u$ の值は求められるからこれを $u_{0}$ とすると, 同式の $u$ の定義から $\sigma_{\max }$ は求められる。

$$
\sigma_{\max }=\left[10^{\left(b+s_{s} u_{0}\right)} D_{f} / g(\eta)\right]^{1 / a}
$$

上式は $\sigma_{\max }$ の許容值等を求めるのに応用できる。

損傷発生率あるいは $\sigma_{\mathrm{max}}$ の許容值に荷重条件等の諸要因がどのように影響するかの解析は (38)，(39)による ときは実に簡単になる。な拉， $D_{s}$ を無視するときはこれらの式中の $g(\eta)$ の代りに $g_{w}(\eta) を$, 逆に $D_{w}$ を無 視するときは $g_{s}(\eta)$ を代入すればよい。

前述のように縦強度材等の疲労損傷も，スチフナ基部のそれと本質的に変わらないから，平均応力の影響が無 
視できるときは(38)，(39)をそのまま適用できる。無視できないときでも，若干の修正で適用できる。いずれの場 合でも煩雑な数值積分は不必要となり，その特性は簡単に解析できる。な怔， $b$ を確率変数として取扱わないと きの損傷が発生する $\sigma_{\max }$ の限界值は(36)より求められる。

\section{$4.4 \sigma_{\max }$ の許容値の想定条件による変化}

$$
\sigma_{\max }=\left[10^{b} D_{f} / g(\eta)\right]^{1 / a}
$$

スチフナ基部の $\sigma_{\max }$ の許容値は，一定の航路を一定の期間就航後のクラック発生に対する $P_{f}$ を， ある基準 值以下になるように定めるのが合理的といえる。この場合に許容値は想定条件によって変化するから，異なる条 件の許容值を比較することは難しかったが(39)より容易に検討できる。

\subsection{1 想定海象}

Fig. 9 亿示す極值は北大西洋に执いて $n_{w}$ が $10^{8}$ のときの極值である。就航海域が 北大西洋と異なるとき は，同一の $n_{w}$ に対する極值はその海域によって定められる修正係数 $K_{r}$ を同図の值に乗じたものになるが，波 浪応力の分布形はやはり指数分布とみなせる。

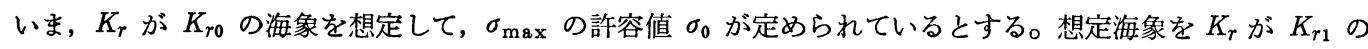
るのに変更した場合は, 前者の海象における $g_{w}(\eta)$ を $g_{w}(\eta)_{0}$, 後者のそれを $g_{w}(\eta)_{1}$ とすると $(34)$ より,

$$
g_{w}(\eta)_{1}=\left(K_{r 1} / K_{r 0}\right)^{a} g_{w}(\eta)_{0}
$$

いま， $g_{s}(\eta)$ が小で無視できるとすると，(34), (39)より

$$
\sigma_{1}=\left(K_{r 0} / K_{r 1}\right) \sigma_{0}
$$

逆に, $g(\eta)$ に含まれる $g_{s}(\eta)$ の比重が大きいときは， $g_{s}(\eta)$ は海象によって変化しないから，

$$
\sigma_{1} \fallingdotseq \sigma_{0}
$$

となる。許容值は想定海象が変化すると $0 \sim\left(K_{r 0} / K_{r 1}\right)$ の值を $\sigma_{0}$ に乗じたものとなる。その間のどの值になる かは， $g(\eta)$ に含まれる $g_{s}(\eta)$ の比重によって変化する。

この比重は $S-N$ 線図の勾配によっても変化し， $a$ が小になる程（勾配は大となる） $g_{s}(\eta)$ の比重は低下する。 これは勾配が大となると，低応力の波浪応力による疲労被害が増大するためである。

4.4.2 航海期間

航海期間を $y_{0}$ 年として許容值 $\sigma_{0}$ が定められているとき，これが $y_{2}$ 年に変化したとすると， $n_{s}, n_{w}$ ともに ( $\left(y_{2} / y_{0}\right)$ 倍に変化する。同時に極值は次式で求められる係数 $K_{y}$ を乗じたものになる。

$$
K_{y}=\left(\log n_{w_{2}} / \log n_{w 0}\right)
$$

これらの関係を(34)に代入すると, 期間変更後の值 $g(\eta)_{2}$ と変更前の値 $g(\eta)_{0}$ の間には次の関係が成立する。

$$
g(\eta)_{2}=\left(y_{2} / y_{0}\right) g(\eta)_{0}
$$

'(34)" を(39) そ代入すると変更前の許容値 $\sigma_{0}$ と変更後の値 $\sigma_{2}$ の関係が求められる。

$$
\sigma_{2}=\left(y_{0} / y_{1}\right)^{1 / a} \sigma_{0}
$$

4.4.3 腐蝕影響, 標準偏差, $P_{f}$ の基準值

前記と同様, $\Delta b_{c}$ を $\Delta b_{c 0}$ として与えられていた許容值が $\sigma_{0}$ のとき，これを $\Delta b_{c 3}$ に変更したとすると, 許 容值 $\sigma_{3}$ は(39)より求められる。

$$
\sigma_{3}=\left\{10\left(\Delta b_{c 3}-\Delta b_{c 0}\right)\right\}^{1 / a} \sigma_{0}
$$

$\Delta b_{c}$ は負の值を有するから， $\Delta b_{c 3}$ の絶対値が大となる程 $\sigma_{3}$ は小となる。

また, 同様にして $s_{s}$ を変更したとき， $P_{f}$ の基準値を変更したときの許容值の修正係数る求められる。許容値 を求める際の基準となる $P_{f}$ は小さな值であるのが普通であるから， $u_{0}$ は負の值になるから $s_{s}$ が大となる程， また $P_{f 0}$ が小となる程許容値は小となる。

\section{5 実船のスチフナ基部の損傷の解析}

前記の SR 120 部会に括いて, 86 隻（第 1 次調查 73 隻, 第 2 次調查 13 隻）の専用船を対象として, ス口 ット部の損傷調査が実施された。このうち主として標本数の多い第 1 次調査結果を疲労損傷の面から検討を加 える。

\section{1 調查船のスチフナ基部の荷重条件}

調查対象船の中のタンカーは主として日本〜ペルシヤ湾航路に就航していたものと推定される。この航路の海 
象は Fig. 8 の想定海象（北大西洋 (Walden)) とは異なる。この場合の船底水圧の長期分布に括ける極値は, 文 献 8）に示す長期分布の性質から求められる。

Table 3 Comparison of effective max wave height $\left(H_{m e}\right)$ on Japan-Persian Bay course with that on N.A. $\left(p_{m j s}=1 \times 10^{-5}, p_{m 0}=1\right)$

\begin{tabular}{|c|c|c|c|c|c|}
\hline $\begin{array}{r}\text { Sea area } \\
T(\mathrm{sec})\end{array}$ & 21 & 23 & 25 & $\begin{array}{c}\text { North } \\
\text { Atlantic }\end{array}$ & $\begin{array}{l}\text { Max. ratio } \\
\text { to N.A. }\end{array}$ \\
\hline $7 \sim 9$ & 9.95 & 9.25 & 8. 95 & 11.83 & 0.84 \\
\hline $9 \sim 11$ & 11.00 & 9.84 & 8.02 & 15.25 & 0.72 \\
\hline $11 \sim 13$ & 11.13 & 10.30 & 10.88 & 15.74 & 0.71 \\
\hline $13 \sim 15$ & 7.54 & 11.17 & 7.96 & 15.74 & 0.71 \\
\hline
\end{tabular}

Table 4 Estimated load condition of web stiffeners on bottom transverses of inspected ships (stress means max value at connection with longitudinal)

\begin{tabular}{|c|c|c|c|c|c|}
\hline \multirow{2}{*}{$\begin{array}{l}\text { Species } \\
\text { of tank }\end{array}$} & \multirow{2}{*}{$\begin{array}{l}\text { Position } \\
\text { of tank }\end{array}$} & \multirow{2}{*}{$\begin{array}{l}\text { No. of } \\
\text { square } \\
\text { station }\end{array}$} & \multicolumn{3}{|c|}{$\begin{array}{c}\text { Still water } \\
\text { stress }\end{array} \mid$ Wave induced stress } \\
\hline & & & $\eta_{s}$ & $\eta_{b}^{\prime}$ & $\eta_{f}$ \\
\hline \multirow{6}{*}{$\begin{array}{c}\text { Ballast } \\
\text { tank }\end{array}$} & \multirow{3}{*}{ Center } & $21 / 2$ & \multirow{3}{*}{1.00} & 0.2071 & 0.1560 \\
\hline & & 5 & & 0.2324 & 0.1336 \\
\hline & & $7^{1 / 2}$ & & 0.1971 & 0.2257 \\
\hline & \multirow{3}{*}{ Wing } & $21 / 2$ & \multirow{3}{*}{1.00} & 0.2309 & $0.3116 \times$ \\
\hline & & 5 & & 0.2740 & 0.3034 \\
\hline & & $7^{1 / 2}$ & & 0.2370 & 0.3933 \\
\hline \multirow{6}{*}{$\begin{array}{l}\text { Ballast \& } \\
\text { Cargo oil } \\
\text { tank }\end{array}$} & \multirow{3}{*}{ Center } & $21 / 2$ & \multirow{3}{*}{0.50} & 0.2071 & 0.1451 \\
\hline & & 5 & & 0.2324 & 0.1609 \\
\hline & & $7^{1 / 2}$ & & 0.1971 & 0.1429 \\
\hline & \multirow{3}{*}{ Wing } & $21 / 2$ & \multirow{3}{*}{0.50} & 0.2309 & 0.1897 \\
\hline & & 5 & & 0.2740 & 0.2260 \\
\hline & & $7^{1 / 2}$ & & 0.2370 & 0.1938 \\
\hline \multirow{6}{*}{$\begin{array}{l}\text { Cargo oil } \\
\operatorname{tank}\end{array}$} & \multirow{3}{*}{ Center } & $21 / 2$ & \multirow{3}{*}{0.25} & 0.1363 & 0.1451 \\
\hline & & 5 & & 0.1370 & 0.1609 \\
\hline & & $71 / 2$ & & 0.1495 & 0.1429 \\
\hline & \multirow{3}{*}{ Wing } & $2 / 2$ & \multirow{3}{*}{0.25} & 0.2569 & 0.1897 \\
\hline & & 5 & & 0.2832 & 0.2260 \\
\hline & & $7 \frac{1}{2}$ & & 0.2707 & 0.1938 \\
\hline Remark & \multicolumn{5}{|c|}{$\begin{array}{l}\eta_{s} \cdots \text { Ratio of amplitude of still water stress to } \sigma_{\max } \\
\text { (standard value) } \\
\eta_{b}, \quad \eta_{f} \cdots \text { Ratio of extreme amplitude of wave indu- } \\
\text { ced stress to } \sigma_{\max } \text { (suffix } b \cdots \text { ballast condition, } \\
\\
f \therefore \text { full load condition) }\end{array}$} \\
\hline
\end{tabular}

疲労が加味された損傷が含まれる心配がある資料を避けることである。
Table 3 は同航路中で最も荒いと思わ. れる 3 個の海域 (Hogben-Lumb の文献 に括ける海域 $21,23,25)$ に打ける等 価最高波高 $H_{m e} \quad\left(p_{m j}=1 \times 10^{-5}, p_{m 0}=\right.$ 1) と北大西洋のそれを比較したもので， $L$ が $200 \mathrm{~m}$ 以上のタンカーの $p, p_{t}$ の 分散が極大值をとる $T_{3}$ が $10 \mathrm{sec}$ 以上 の海面の $H_{m e}$ は北大西洋の $70 \%$ 程度 になる。したがって, 調査対象船が長期 間同海域を航海したときの, $p, p_{t}$ 等の長 期分布に拈ける任意の $Q$ に対する極値 は, Fig. 8 に示す值の約 $70 \%$ とみてよ W。

また，調查対象船の船齢は種々のもの があるが，平均船齢は約 4 年であるので 4 年とする。これらの船の 1 航海日数を 34 日, 年間航海数を 8 回, 平均波周期を $12 \mathrm{sec}$ とすると，4年間の静水応力繰返 し数 $n_{s}$ ，バラストおよび満載時（航海 日数は等しいとする）の波浪応力繰返し 数 $n_{w b}, n_{w f}$ はそれぞれ次の值になる。 $n_{s}=32$ $\left.n_{w b}=n_{w f}=n_{w}=3.9168 \times 10^{6}\right\}$

以上の仮定から導かれた推定荷重条件 をまとめると，Table 4 のようにな る。同表中の $\eta_{s}$ は前述の静水王力の変 化から求めた近似值で, バラスト専用タ ソクは両振，他は片振荷重である。 $\eta_{b}$, $\eta_{f}$ は Fig. 9 の值に次に示す值の $K_{r}, K_{l}$ を乗じたものである。

$$
\left.\begin{array}{l}
K_{r}=0.7 \\
K_{y}=\log n_{w} / 8=0.8241
\end{array}\right\}
$$

\section{2 実船の損傷調查結果からみた} $\Delta \boldsymbol{b}_{c}$ および $\boldsymbol{s}_{\boldsymbol{s}}$

5.2 .1 対象とした損傷調查結果

SR 120 部会の調查項目は多方面にわ. たっているので， $P_{f}$ の計算值との比較 検討に適したものを選ぶ必要がある。こ の場合重要なことは, 実船の損傷原因は 単純でないるのがあり, 特に静水応力と 波浪応力による㽻学に, 振動応力による。

この見地から, Table 5 に示す振動の影響が少ないといわれている B 2 扎よび B 5 部 (Fig. 12 参照) タン ク種別損傷発生率と, この部分の $\sigma_{\max }$ と $P_{f}$ の関係, および Fig. 16 に示す $P_{f}$ の経年変化を資料として選: 
んだ。

5.2.2 $P_{f}$ の推定

調查対象船の $\sigma_{\max }$ の分布は, $68 \mathrm{~kg} / \mathrm{mm}^{2}$ を中位値として $0 \sim 150 \mathrm{~kg} / \mathrm{mm}^{2}$ の範囲にわたって各応力ほとんど等頻度に分布している。よって， $\sigma_{\max }$ は 34 , $68,110 \mathrm{~kg} / \mathrm{mm}^{2}$ のものがそれぞれ $1 / 3$ の確率で存在すると仮定した。ここで いう $\sigma_{\max }$ の值は，たとえば $\mathrm{B} 2$ 部を例にとると $\mathrm{B} 2$ 部にあるスチフナの $\sigma_{\max }$ の平均であるが，平均値で代表させても誤差は大きくないと推定される。

$\sigma_{\max }$ は三井千葉研の計算式によって求められて和り，これはスチフナの上 端を支持してないときの值であり, 船底トランス付スチフナの中で上端の支持

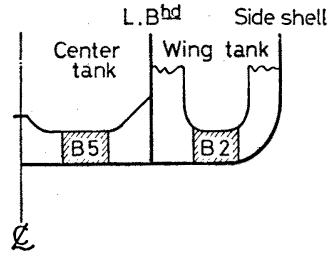

Fig. 12 Location of $\mathrm{B} 2$ and B 5

条件がこれに近いるのは多くて $1 / 5$ 程度と推定される9)。したがって, 偏心型については与えられた $\sigma_{\max }$ につ いてそのまま $P_{f}$ を計算すると過大評価になるので，実際の $P_{f}$ は与えられた $\sigma_{\max }$ に対する值の $1 / 3$ になると した。偏心型に怙いてはスチフナ上端を支持すると $\sigma_{\max }$ は約 $1 / 2$ 亿低下する。よって, $\sigma_{\max }$ が任意の值 $\sigma_{\max 1}$ の多数のスチフナでは基部応力が $\sigma_{\max 1}$ のものが $1 / 5, \sigma_{\max 1} / 2$ のものが $1 / 5$, 中間の值のものが $3 / 5$ の比で 存在するとして $P_{f}$ を求めた結果と比較すると， $\sigma_{\max 1}$ が大きいる上記の $1 / 3$ 亿修正する方法ではやや過少な $P_{f}$ を兄るが，後述のようにこの方法による $P_{f}$ の值は $\sigma_{\max 1}$ が大きいときでも過小ではない。

SR 120 部会の調査対象船ではバックブラケットは汪とんど使用されてないので, 偏心型の $S-N$ 線図を使用 し $t_{s}$ は $12 \mathrm{~mm}$ とした。また， $D_{f}$ は 1 亿達すると損傷が発生すると仮定した。

5.2 .3 B 2, B 5 部の損傷発生率

Table 5 に示す $P_{f}$ の調查結果を,

a) 荷重条件が比較的正確に推定できるもの

b）振動の影響が加わりやすい後部タンンの資料が多く含まれてないるの

c) 標本数が多いもの

といら条件からその精度を検討した。

荷重条件の点ではバラスト専用タンクに分類されたものが最も正確であり, バラスト兼用タンクがこれに続 く。調查対象船（第 1 次調査）は昭和 43 年以前に建造された船で, 貨物油タンクに分類されたものでも，バラ スト兼用タンク等に使われたものも含をれていると推定される。

標本数の船長方向分布をみると，バラスト専用タンクは船尾部はほとんど0であり，他のタンクは船尾部の方 が多い。また，同表に明らかなように，バラスト専用タンクのB 5 部, バラスト兼用タンクの B 2 部は極端に少 ない。

以上を総合して, バラスト専用タンクの B 2 部の $P_{f}$ が最も精度がよく, 同兼用タンクの B 5 部がこれについ で信頼できる。この精度の差を考えて, 試行錯誤法によって, $\Delta b_{c}$ 执よび $s_{s}$ の值を推定した結果

$$
\left.\begin{array}{c}
\Delta b_{c} \fallingdotseq \log 0.6 \\
s_{s} \doteqdot 0.4
\end{array}\right\}
$$

とするのが妥当であろうとの結論に到達した。この值は $s_{s}$ がやや大きいが, SR 120 部会で求められた值と大

Table 5 Comparison of $P_{f}$ at B5 and B2

\begin{tabular}{c|r|r|r|c}
\hline \hline \multirow{2}{*}{ Species of tank } & \multicolumn{2}{|c|}{$P_{f}$ (Inspection) $(\%)$} & \multicolumn{2}{|c}{$P_{f}$ (Estimation) $(\%)$} \\
\cline { 2 - 5 } & B5(Sample size) & B2(Sample size) & \multicolumn{1}{c|}{ B5 } & B2 \\
\hline$B$ & $1.92(104)$ & $8.05(1304)$ & $6.25(1.68)$ & $9.86(9.03)$ \\
\hline$B / C$ & $1.98(1114)$ & $2.54(236)$ & $2.42(2.59)$ & $5.42(6.09)$ \\
$C$ & $5.19(2754)$ & $9.18(4073)$ & $1.96(2.00)$ & $5.63(6.69)$ \\
\hline$B / C+C$ & $4.27(3868)$ & $8.82(4309)$ & - & - \\
\hline$B+B / C+C$ & $4.20(3972)$ & $8.64(5613)$ & - & - \\
\hline
\end{tabular}

$B \cdots$ Ballast tank, $B / C \cdots$ Ballast \& Cargo oil tank, $C \cdots$ Cargo oil tank 
体一致する。Table 5 の $P_{f}$ の推定值は上記の值を使用した計算値である。

計算值は横断面 $2 \frac{1}{2}, 5,7 \frac{1}{2}$ に打ける $P_{f}$ を求め, それに対象とするタンクの後部, 中央部, 前部の標本数の 概数を重み係数として乗じて求めた加重平均值である。ただし，バラスト兼用拉よび貨物油専用タンクでは後部 計算值と調查結果の差が大きいので, この部分はさらに振動による損傷が加味されるものと考え, 調査結果（B 2 部 $9.1 \%$ ，B 5 部 4.5\%) を $P_{f}$ とした。これから見て，B 2 扎よび B 5 部でも船尾部では相当振動の影響が 加わっているのではないかと思われる。

同表に示すように，種々の悪条件があるにかかわらず計算值と調查結果はかなりよい一致がみられる。な特同 表に拈いて，貨物油タンクはその荷重条件の不正確さからみて，これとバラスト兼用タンクを同一グループと し，バラスト兼用タンクの計算值と比較する方が妥当と思われる。

Fig. 13 は船底各部の $g(\eta)$ を比較したもので, $\eta_{b}, \eta_{f}$ の差が強調された形になり, 玄側タンクの $g(\eta)$ は 明らかに中央タンクより大であり，その結果 $P_{f}$ の計算值は常に B 2 部の方が高い。これは調査結果ともよく一 致するが, B 2 部よりさらに $g(\eta)$ が大となるビルジ部の $P_{f}$ はB 2 部より小となることが多いといら点は一致 しない。な括 $g(\eta)$ が最大となる船首部玄側のバラスト専用タンクで $P_{f}$ が高くなるという調査結果は少くとも 第 2 次調查では得られている。

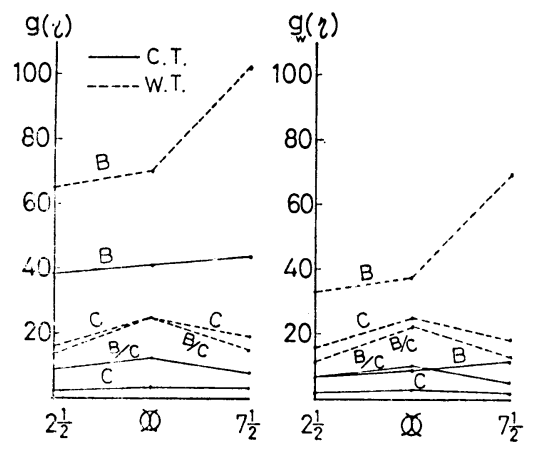

Fig. 13 Comparison of $g(\eta)$ and $g_{w}(\eta)(B \cdots$ Ballast tank, $B / C \cdots$ Ballast \& cargo oil tank, C...Cargo oil tank)
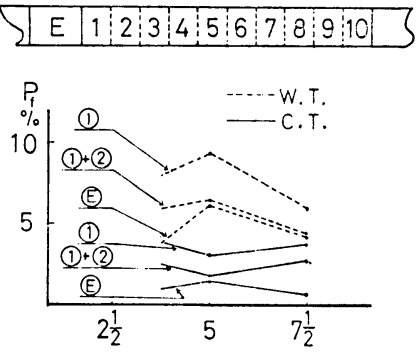

Fig. 14 Longitudinal distribution of $P_{f}$

(1): 1st inspection, (2):2nd inspection (6): Estimated $P_{f}$

また，バラスト専用タンクと他のタンクでは $g(\eta)$ に大きな差があるのに, 調査結果ではそれほどの差は見ら れない。これは，1つは前述の振動影響によるが，他に次のことが考えられる。同図に示す $g(\eta)$ の差は $g_{s}(\eta)$ の差（バラスト専用タンクは 32 , 他はその $1 / 10$ 以下）が相当大きく寄与している。したがって，図示のよらに $g_{w}(\eta)$ の差は $g(\eta)$ 差ほど大きくない。 $g(\eta)$ の中の $g_{s}(\eta)$ の比重は係数 $a$ によって変化し， $a$ が小となる程 $g_{s}(\eta)$ の比重は小となる。腐蝕の影響は $a$ を減少させる作用はあるが，ここでは無視しているから，計算值はタ ンクによる $P_{f}$ の差を過大に見積ることになる。また， $\sigma_{\max }$ が大となるときは $S-N$ 線図を高応力算囲まで直 線で延長した誤差も考えられる。

Table 5 の（）内の計算值は疲労被害度として $D_{w}$ のみをとり， $\Delta b_{c} ， s_{s}$ は次の值としたときの計算值であ る。

$$
\left.\begin{array}{c}
\Delta b_{c} \fallingdotseq \log 0.4 \\
s_{s} \fallingdotseq 0.4
\end{array}\right\}
$$

見方によってはこの場合の方が調査結果とよく一致する。しかし， $D_{s}$ は常に無視してよいかどらかはなお検 討を要すると思われる。

な拈，計算值と調査結果は局部的には若干の不一致が見出される。Fig. 14 はその一例で $P_{f}$ の船長方向分布を 比較した結果で, 横断面 $2 \frac{1}{2}$ ではタンク全長を 10 等分したときの区分位置 1,2 が, 同様 5 には区分位置 5 , $7 \frac{1}{2}$ には区分位置 8，9 の $P_{f}$ が対応するとした。前述のように計算値はハララスト専用タンク以外は低目に出る ので, 標本数を考えた加重平均值をとると相当の差を生じる。ただし, 図示のように第 1 次, 第 2 次調査の結果 を合わせると，その差は小となる。 


\section{$5.2 .4 \sigma_{\max }$ と $P_{f}$ の関係}

Fig. 13 亿示すように, 大体は $g(\eta)$ の船長方向の変化は大きくないから, 船体中央の值で代表させることが できる。また, Table 5 飞示すように, 全タンクを総合した $P_{f}$ の值は, バラスト専用タンクの值に近い。以上 からバラスト専用タンクの船体中央における中央タンクと玄側タンクの荷重条件の平均値となる荷重条件を選び これを標準荷重とし，この荷重が負荷されたときの $\sigma_{\max }$ と $P_{f}$ の関係を求めると，全タンクの $\sigma_{\max }$ と $P_{f}$ の 関係にほぼ近い結果を与える。

標準荷重としては插間法によって求めた中心線から B/4 離れた点の次に示す荷重条件をとる。

$$
\left.\begin{array}{l}
\eta_{b}=0.2601 \\
\eta_{f}=0.2468
\end{array}\right\}
$$

Fig. 15 は $\Delta b_{c}, s_{s}$ に(44)の值を使用し, 標準荷重に括 ける $\sigma_{\max }$ と $P_{f}$ の関係を求めた結果で, 四中鎖線で示し た調査結果とよく一致する。 $\sigma_{\max }$ が $100 \mathrm{~kg} / \mathrm{mm}^{2}$ を超え ると $P_{f}$ の計算值はやや過大になるが， $\sigma_{\max }$ がこのよう な值になるのは基部に比較的大型の $1 / 4$ 円形切欠きを有す るスチフナが多い。 $\sigma_{\max }$ の計算式の想定条件からみて, このよらなスチフナでは基部の偏心曲げ応力が特に大にな るが，実際は基部の剛性が低下すればそれだけスチフナ上 端の支持条件が計算式のそれに近いるのの発現確率は小と なるから， $P_{f}$ の計算値は過大になると推定される。 $\sigma_{\max }$ が低いのに損傷が発生したものには振動の影響が加わった 場合が考兄られるから， $\sigma_{\max }$ が $50 \sim 100 \mathrm{~kg} / \mathrm{mm}^{2}$ に怙け

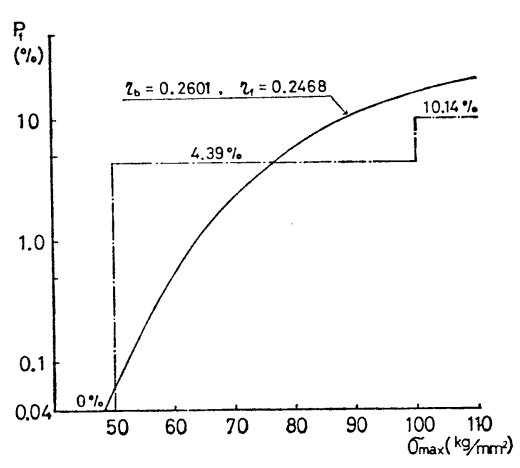

Fig. 15 Relation between $\sigma_{\max }$ and $P_{f}$ under standard load condition expressed by Eq. (46) る $P_{f}$ が最も信頼できるといえるが，この応力範囲の中位値付近で計算値と調査結果が一致する。

船底トランス付スチフナの総数を約 2500 と仮定し， $P_{f}$ が 0 といら調査結果は計算值の $P_{f}$ が $1 / 2500$ 以下 である場合に対応するとして, このときの $\sigma_{\max }$ を求める。 $P_{f}$ は計算值の $1 / 3$ 亿低下するとしているから,

$$
\left.\begin{array}{l}
\Phi\left(u_{0}\right)=3 \times(1 / 2500) \\
\therefore u_{0}=-3.04
\end{array}\right\}
$$

上記の $u_{0}$ に対する $\sigma_{\max }$ を(39) より求めると約 $48 \mathrm{~kg} / \mathrm{mm}^{2}$ となり, ほぼ $\mathrm{SR} 120$ 部会の解析結果と一致する。

バラスト専用タンクの荷重条件を想定した結果が実船の $P_{f}$ と一致するといらことは, 振動等による影響が含 まれた結果とすると，今後防振対策が十分にとられたとき 飞は，ここに示す $P_{f}$ の計算値は過大となる。このような 時点においてはタンクの種類別に中央の平均荷重を標準荷 重とすればよいと思われる。

\subsection{5 $P_{f}$ の経年変化}

Fig. 16 は $\sigma_{\max }$ が $60 \mathrm{~kg} / \mathrm{mm}^{2}$ 以上のスチフナ $\left(\sigma_{\max }\right.$ が $110,75 \mathrm{~kg} / \mathrm{mm}^{2}$ のスチフナがそれぞれ同数含まれると した）に持ける年間損傷発生率の経年変化を求めた結果を 示す。 $P_{f}$ の推定は若干精密化して, $\sigma_{\max }$ が計算上同一 の值のスチフナでも上端の支持条件は種々のものが存在す るとして, 支持されないもの, 完全に支持されたもの, 中 間の状態のすのがそれぞれ $1: 1: 3$ の比で含まれるとし た。荷重条件は前述の標準荷重とし， $\Delta b_{c} ， s_{s}$ の值は (44) の値を代入した。

計算值で $P_{f}$ が極大になるのは $2 \sim 3$ 年で, 調査結果と 比べると 1 年早い。 $\sigma_{\max }$ が $75 \mathrm{~kg} / \mathrm{mm}^{2}$ のスチフナの $P_{f}$ 恃比較的值が小であり 7 年以前にモードはなく, 全体のモ 一ドがあらわれる船齢は $110 \mathrm{~kg} / \mathrm{mm}^{2}$ のスチフナのそれと
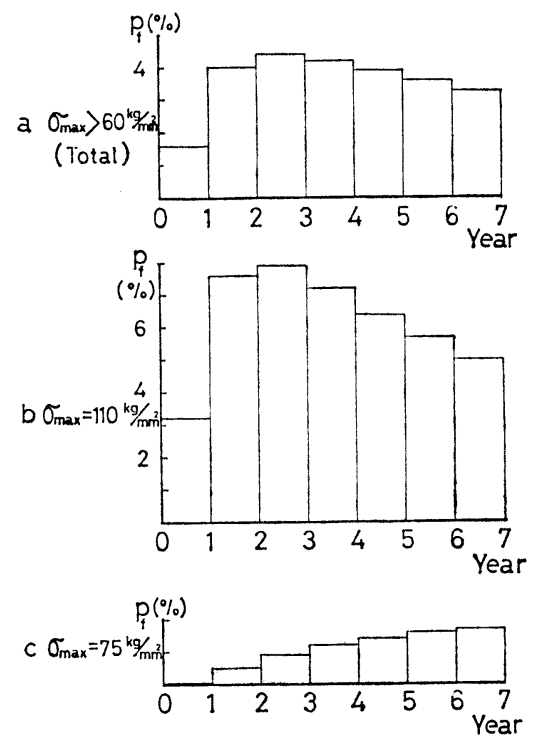

Fig. 16. Variation of $P_{f}$ by ships' age 
一致する。スチフナのモードは $\sigma_{\max }$ が大となる程早く現われる。したがってこの場合は $\sigma_{\max }$ が $110 \mathrm{~kg} / \mathrm{mm}{ }^{2}$ のスチフナを想定することが問題になる。

この事実と前述の $\sigma_{\max }$ が $100 \mathrm{~kg} / \mathrm{mm}^{2}$ を超える場合 $P_{f}$ の計算値は調查結果よりやや過大になるといらこ とから，偏心型のスチフナで計算上 $\sigma_{\max }$ が $100 \mathrm{~kg} / \mathrm{mm}^{2}$ を超える場合，実際に $\sigma_{\max }$ がその值になる確率は 極めて低く， $\sigma_{\max }$ の上限值はたかだか $100 \mathrm{~kg} / \mathrm{mm}^{2}$ とみても危険はないといえる。

なお， $\sigma_{\max }$ が $60 \mathrm{~kg} / \mathrm{mm}^{2}$ 以下の場合は，7年以前にはモードは現われない。調査結果では $60 \mathrm{~kg} / \mathrm{mm}^{2}$ 以下 です 7 年以前にモードが現われているが, これはここで考える波浪応力等による疲労の他に振動等の他の原因が 影響した損傷と判断される。

実船に浐ける $P_{f}$ の経年変化では, 同図のるのよりもモードは鋭い形をとっている。これは想定したの 值とその值を有するスチフナの数の組合わせによると思われるが，計算では似た形の組合わせは見出せなかっ た。なお，モードの現われる船龄は前述の $P_{f}$ は計算値の $1 / 3$ になるとする近似法，あるいは $s_{s}$ の值によって 変化するもので，まだまだ検討すべきことが残されている。

\section{3 スチフナ基部応力の許容値}

SR 120 部会に拈いて $\sigma_{\max }$ の許容值を検討した際の想定条件は次のようになる。

a）想定海象…日本〜ペルシヤ湾航路

b) $P_{f 0} \cdots$ 就航 4 年後で $1 / 2500$ 以下

c) $\Delta b_{c}=\log 0.8, s_{s}=0.3$

d）標準荷重…船体中央・中心線上に拉けるバラス ト専用タンクの荷重

上記の条件を踏襲し, 荷重は本稿で示した標準荷重と したときの許容値を(39)より偏心型について求めた結 果を Table 6 に示す。SR 120 部会の結果より若干高 目の值であるが，これは $S-N$ 線図として偏心型のものを採用したためといえる。な拉述のように $s_{S}$ は同 部会のより若干高めになるという結果が得られているが，腐蝕対策が十分行われるということを前提とすると $s_{s}$ 〕となると考光，0.3 を採用した。これらの条件を修正した場合の許容值の孪化は既述のように容易に求め られる。

なお，釣合型については，カラーを併用している場合は $t_{s}=12 \mathrm{~mm}$ で約 $34 \mathrm{~kg} / \mathrm{mm}^{2}$, カラーを併用しない場 合には $37 \mathrm{~kg} / \mathrm{mm}^{2}$ といら值が得られる。これは釣合型の $S-N$ 線図を代入したのが主な原因となっている。他 にスチフナ毎の $\sigma_{\max }$ のバラッキが構造によって異なることも $P_{f}$ の計算には配慮し, 釣合型でカラーを併用し たものの $P_{f}$ は計算值のまま，他は計算值の $1 / 5$ に低下寸ると仮定しているが，その影響は大きくないよらであ る。

偏心型については，前述のように実船の損傷実績と推定値の比較もし，推定値は信頼できるが，釣合型につい てはこのようなことは行ってないから，果して上記の許容値がどの程度の精度を有するかは不明であるので，表 から除外した。

ただ，現在の知識からは釣合型に対しては許容值を低目にとる方が好ましいといえる。

\section{6 結言}

本論文は船底トランスのウェブスチフナ基部に働く荷重, スチフナの疲労損傷発生率の推定方法, およびこれ らの研究から得られた知識と模型試験結果から求められたスチフナ基部の損傷と実船のスチフナ基部損傷の調查 結果との比較検討等についての研究をまとめたものである。

荷重条件については船底の主要な点の船底外板に働く船体運動による変動内压も含めた波浪荷重を求め, これ からスチフナ基部の荷重条件がスチフナの位置，タンクの使用条件によって如何に変化するかを調べた。波浪応 力は中央タンクと玄側タンクとでは相当の差があり，船長方向には大きな変化はない。ただ，船首部玄側のバラ ストタンクは相当大きな值になる。タンクの種別でみると玄側ではバラスト専用タンクが最も大で，他のタンク には大きな差はない。中央タンクでは貨物油タンクが若干小で，他のタンクの差は小さい。

静水応力ではタンクの種類の差が顕著で, バストタンクが最も苛酷でバラスト兼用タンク, 貨物油タンクの 
順になる。総合した荷重条件は $g(\eta)$ で表わされるが，その順序は前記のるのと同じたなる。

疲労損傷発生率の推定のために筆者等はスチフナの基準応力（設計応力）と荷重条件が与光られると損傷発生 率を，また逆に損傷発生率が一定値以下になる基準応力の許容值を求められる解析方法を導いた。この方法はス チフナ基部たけでなく, 緃強度材等の疲労解析にも応用できる非常に有用な解析方法である。また，この解析法 によると許容応力に与える想定条件の影響を簡単に知ることができる。

前記の荷重条件と疲労損傷解析方法を適用し, これに SR 120 部会の模型試験結果から求めた偏心型の $S-N$ 線図を用いて推定した損傷発生率と実船の損傷実績を比較した結果では, 腐蝕により疲労寿命は約 0.6 倍に低下 し; 寿命の対数のバラッキを示す標準偏差は 0.4 程度とするとかなりよい一致がみられる。しかし，一致しない ものも多くその顕著なのは船尾側タンクで, 従来振動の影響が少ないとみられた部分でも振動の影響は相当加わ っているのではないかと思われる。

また，スチフナ基部の応力を三井千葉研式で求めた場合， $100 \mathrm{~kg} / \mathrm{mm}^{2}$ を超觉るるのが見出されることがある が，スチフナ上端の支持条件抢よび損傷発生率等から，このようなるのの実際の応力は $100 \mathrm{~kg} / \mathrm{mm}^{2}$ 程度とみな してもよいことが明らかになった。

船体中央の中心線より $\mathrm{B} / 4$ 離れた点のバラスト専用タンクの荷重条件を標準荷重とすると, 全体の損傷発生率 を推定できることが明らかとなった。しかし，これは見掛け上の損傷発生率であるから，防振対策等が進めば変 化すると思われる。この標準荷重を使用してスチフナ基部の許容応力を推定すると, 偏心型では SR 120 部会の 值は若干安全側にあることが明らかになった。

本研究は日本造船研究協会第 120 研究部会の研究を基礎として, これを発展させたものであり, その間貴重な 意見と絶えざる激励を頂いた秋田好雄部会長をはじめ委員の方々に深甚な謝意を表します。また, 疲労強度につ いて貴重な意見を頂いた同協会第 200 研究部会第 2 分科会の寺沢一雄阪大名誉教授，八木順吉主査はじめ委員の 方々，数値計算結果を提供され援助を頂いた日本海事協会コンピュータ室の方々，波浪荷重について貴重な意見 を頂いた別所正利防衛大教授に篤く感謝します。

\section{参考 文 献}

1）第 120 研究部会: 大型船の横部材に招けるスロット周辺のクラック防止に関する研究, 日本造船研究協会 報告第 76 号, (昭和 49 年).

2）秋田好雄, 枡田吉郎, 山口勇男, 田代新吉, 新田 顕, 日高正孝, 筒井康治, 湯浅通史, 日笠則明, 津村 道夫：船体税強度解析に関するトータルシステム, 日本造船学会論文集第 135 号, (昭和 49 年).

3）福田淳一：船体応答の統計的予測, 日本造船学会, 耐航性飞関するシンポジゥム, (昭和 44 年).

4) 真能 創, 上野洋純: 波浪飞対する各種船体応答の長期分布の近似推定法とその応用, 日本造船学会論文 集第 132 号, (昭和 47 年).

5）船体構造委員会関東地区部会，スロット対策愁談会：大型船の横桁材におけるスロット周辺の損傷防止に 関する検討（その 1 ), 日本造船学会誌第 505 号, (昭和 46 年).

6）飯田國廣, 井上 肇: 低サイクル疲労寿命の分布形状に基づいた疲労設計曲線の一考察, 日本造船学会論 文集第 133 号, (昭和 48 年).

7）高橋幸伯：船体構造に括ける疲れの問題, 東京大学学位論文, (昭和 36 年).

8）真能 創：海洋波に対する応答の長期分布の理論的推定における想定海象について, 日本造船学会論文集 第 135 号, (昭和 49 年).

9）安東重美, 西原誠一郎：スロット部スチフナ基部応力におよぼす横析面外変位の影響について, 日本造船 学会誌第 519 号, (昭和 47 年). 